\title{
VARIETIES OF GREEK: DISORDER AND CONTINUITY
}

\section{Stephen Colvin}

Social magic always manages to produce discontinuity out of continuity. Bourdieu, Language and Symbolic Power ${ }^{1}$

1. Social dialect, which can be defined negatively as dialect associated with variables other than geographic region, was hardly recognized as a linguistic category until the twentieth century. Although it has been recognised since antiquity that groups at the bottom of the socio-economic ladder speak differently from the elite, non-elite idioms did not merit serious investigation since they were regarded merely as a corrupt or decadent approximations to the prestige variety. There is evidence that Greeks also recognised gender as a variable in linguistic production. Age occasionally figures in discourse about language, but the association is vaguer since it was tangled up with the idea that earlier generations spoke a better or more authentic form of Greek.

Writing a grammar of a vernacular (or stigmatised spoken variety) is inconceivable in a social context in which such varieties are thought to be essentially ungrammatical; and it may even be offensive in a context in which the standard symbolizes the purity, heritage or identity of the community, perhaps by association with a body of culturally important texts, even (or especially) if the variety in question is spoken by a large chunk of the population. The idea that social dialects are mutations or modifications of the standard

\footnotetext{
${ }^{1}$ P. Bourdieu, Language and Symbolic Power II 4 (ed. J.B. Thompson, tr. G. Raymond and M. Adamson, Cambridge 1991), 120; original version 'Les rites comme actes d'institution', Actes de la recherche en sciences sociales 43 (Rites et fétiches) (1982), 58-63, at 60.
} 
language was common in the ancient world, and is still widespread. It implies that the mutation has a cause which can be identified, as opposed to the standard, which exists as the legitimate unmarked variety and calls for no particular explanation, being the natural expression of the healthy organism (the body politic, or its truly free citizens). ${ }^{2}$ This was not, so far as we can tell, the way that regional dialects were conceived in the Greek world, since there was no supra-regional standard until the Hellenistic period. The status of the classical dialects (or at least, of their literary standards) was remembered in the postclassical period; and even after the establishment of the Attic-based koine local communities in the old Greek world continued to write Greek with elements of regional dialect until well into the Roman period, while a handful of regional koinai (coloured with West Greek features) competed with the Attic-based koine. ${ }^{3}$ The overlap between regional and social dialect is complex, and the distinction between them is relatively recent. A social dialect can be connected with a region, or a neighbourhood in a city (such as the Piraeus); in many cultures the prestige dialect is connected with a specific urban centre, and regional dialects may be stigmatized. Analysis of the social varieties of Greek is closely connected with a general view of the Greek language and the regional dialects. Central to the perception that varieties of language (regional or social) are variations or mutations of the standard are the following positions:

a) as a general principle language moves from unity to diversity; and

\footnotetext{
${ }^{2}$ Those citizens who have a 'liberal education' ( $\dot{\lambda} \lambda \varepsilon \cup \theta \varepsilon$ proৎ $\pi \alpha 1 \delta \varepsilon i ́ \alpha$ Arist. Politics 1338 a30) that is not directed at making a living. See K. Raaflaub, 'Democracy, Oligarchy, and the Concept of the 'Free Citizen' in Late Fifth-Century Athens', Political Theory 11 (1983), 517-44. ${ }^{3}$ Regional koinai developed in north-west Greece (the Aetolian league), the north-central Peloponnese (the Achaean League), Sicily, and Rhodes. See V. Bubeník, 'Formation of Doric Koines', Encyclopedia of Ancient Greek Language and Linguistics (Leiden 2013); A. Striano, 'Koiné, koiná, koinaí: are we talking about the same thing?' in G. Giannakis et al. (edd.), Studies in Ancient Greek Dialects (Berlin 2017), 131-47.
} 
b) a language variety is essentially connected with a defined group of speakers (such as an ethnic group).

The first point includes the (useful heuristic) supposition that a parent language is a unity, a homogeneous entity from which the daughter languages derive by innovation and divergence (either a reconstructed proto-language such as Indo-European, or an attested language such as Latin). It also covers the vaguer notion that linguistic diversity and messiness represent a decline from an earlier period of purity, which may have been as recent as a generation or two ago. The written standard is almost always the representative and symbol of that earlier uniform and ordered language.

A strong version of point $(b)$ has been abandoned in most recent academic discourse; the early view articulated by Kretschmer, for example, which proposed that the 'Greeks' arrived in Greece in three waves (first the Ionians, then the Achaeans - a term which included Aeolians - and finally the Dorians after 1200 в.C.E..), ${ }^{4}$ was generally rejected by the mid-twentieth century. Arguments over the Dorian invasion and other pre-historic 'dialectal migrations' rumbled on (the movement of Ionic-speakers and Aeolic-speakers from mainland Greece to the eastern Aegean, for example). ${ }^{5}$ It is true that an ethnic group will often use language as part of the definition of its ethnicity. What is now generally disputed is whether it is possible to retroject the group and its ethnic identity back to an earlier undocumented or prehistoric period and then trace its migration into the historical

\footnotetext{
${ }^{4}$ P. Kretschmer, 'Zur Geschichte der griechischen Dialekte', Glotta 1 (1909), 1-59.

${ }^{5}$ Recently H.N. Parker, 'The linguistic case for the Aiolian migration reconsidered', Hesperia 77 (2008), 431-464, with a response by J.L. García Ramón, 'On the genetic classification of ancient Greek dialects: comparative reconstruction versus hypercriticism and atomism at work', Studies in Greek Linguistics 30 (2010), 219-236; N. Mac Sweeney, 'Separating fact from fiction in the Ionian migration', Hesperia 86 (2017), 379-421; E. Pulgram, 'Linear B, Greek and the Greeks', Glotta 38 (1960), 171-181, had already set out the contradictions inherent in the extension of nomenclature (names of peoples and languages) to undocumented periods in the construction of aetiologies.
} 
period. Less often disputed is the status or definition of the language in question (the reality underlying the dialect referred to as Ionic, or Doric, etc.); in most cases this is a projection of the mythical ethnos. ${ }^{6}$

A version of (b) which has not been entirely abandoned is the connection between a language variety and a social group like a socioeconomic or occupational category, or gender. On the one hand, a social group can generally be more clearly defined than an ethnic group: women, men, slaves can be pointed to, while ethnic group membership is more complex and usually self-defined, or at least a negotiation between self-definition and external ascription. But there is a sliding scale, on which 'essential' categories are likely to be unstable when pressed. As Bourdieu argued,

"The notion of "popular speech" is one of the products of the application of dualistic taxonomies which structure the social world according to the categories of high and low (a "low" form of speech), refined and coarse (coarse language) or rude (rude jokes), distinguished and vulgar, rare and common, well mannered and sloppy: in short, categories of culture and nature. [...] These are the mythical categories which introduce a decisive break in the continuum of speech forms, ignoring, for example, all the overlapping that occurs between the relaxed speech of dominant speakers (the fam.) and the tense speech of dominated speakers [...] and above all the extreme diversity of

\footnotetext{
${ }^{6}$ As Condillac wrote: 'Tout confirme donc que chaque langue exprime le caractère du peuple qui la parle' (Essai sur l'origine des connaissances humaines, Paris 1798; Seconde partie, du langage et de la méthode. Section première, ch. 15 'Du génie des langues', p. 143). This echoes an idea about language that can be seen in Isocrates, and was ascribed to Ennius (Aulus Gellius, Noctes Atticae 17.17). For Condillac it was part of the revolutionary programme to teach the standard language to the masses, since without a proper language they would never be able to achieve their full potential; but a side effect of a standard language, as Bourdieu observed, is the advantage acquired by the social class for whom it is a first language (n. 1, 47; original version Ce que parler veut dire, Paris 1982, 30).
} 
speech forms which are universally relegated to the negative category of "popular speech"."

All linguistic communities are equally messy at all periods. By 'messy' I mean that they have numerous competing variants at all levels (phonological, morphological, lexical), and subsume numerous varieties made up of intersecting isoglosses. The notion that an earlier stage of a language was uniform is at least partly the result of the culture of a corpus language; if only written records remain, these are likely to witness the written standard. Additional ideological value derives from the frequent association of a written standard with a prestigious literary canon (since a standard most often has that status by virtue of this connection).

Even though modern linguistics maintains a distinction between regional dialect and social dialect, it is worth observing that the Greek regional dialects (like many popularly defined dialects) are cultural and historical constructs. The term Doric, for example, has little substantial linguistic content. It covers a vast and not clearly-defined range of territory from the Corinthian gulf to Rhodes, with few common elements that we can be sure of apart from a handful of inherited features (only common innovations constitute evidence of a meaningful dialect grouping). ${ }^{8}$ The Greek dialects are in effect organisational devices in modern scholarship. The ancient ethnic/political terms were revived and expanded in the context of nineteenth-century linguistic and biological

\footnotetext{
${ }^{7}$ Bourdieu (n. 1), 93; original version 'Vous avez dit “populaire”?' Actes de la recherche en sciences sociales 46 (L'usage de la parole) (1983), 98-105, at 100.

${ }^{8}$ A. Meillet, Aperçu d'une histoire de la langue grecque (Paris 1913), 104-106. The north-western dialects are often included in the term Doric by modern linguists, though speakers (e.g in Elis, Phocis) did not necessarily regard themselves as Dorians. J. Méndez Dosuna (Los dialectos dorios del noroeste, Salamanca 1985, 316-26) has a useful review of the evidence and makes the case for the Doric future in -se- as an innovation exclusive to 'protodorio'.
} 
science. We have no control over our data, which in a circular fashion reflect and confirm the local standards that were largely created or defined by writing. The data comprise a relatively small number of urban standards, and almost no inscriptions at all from large parts of the Greek world until the Hellenistic period (including Laconia, Messenia, Thessaly, Lesbos and northern Greece). ${ }^{9}$

2. The connection of a language with a group of speakers who migrated at a poorlydocumented period to the historical homeland is relevant to social dialect to this extent: it bolsters the idea of an underlying metaphysical pattern whereby a language exists, then splits. ${ }^{10}$ For Greek, the pattern would start with proto-Greek, spoken by newly-arrived 'proto-Greeks' in the Balkan peninsula; this then split into the historical dialects (via their shadowy second-millennium forerunners) as the speakers headed in different directions across what became the historical Greek territories. In the cities or regions the local dialect further diversified into standard and variations (the standard gave rise to variations).

\footnotetext{
${ }^{9} \mathrm{C}$. Brixhe, 'Situation, spécificités et contraintes de la dialectologie grecque', in id. and G. Vottéro (edd.), Peuplements et genèses dialectales dans la Grèce antique (Nancy 2006), 39-69. See J.L. García Ramón, 'Ancient Greek dialectology: old and new questions, recent developments' in G. Giannakis et al. (edd.), Studies in Ancient Greek Dialects (Berlin 2017), 29106 , for a defence of the traditional groupings.

10 'Nous verrons ... que dans sa volonté de mettre de l'ordre dans le désordre la linguistique a parfois tendance à dériver vers le rêve d'un ordre supérieur, d'une langue originelle, voire d'un « intelligent design ». Un regard sur l'histoire récente, celle pour laquelle nous avons des traces tangibles, nous donne pourtant une autre leçon.' L-J. Calvet, 'Pour une linguistique du désordre et de la complexité', in P. Blanchet, Philippe, L.-J.Calvet, D. de Robillard (edd.), Un siècle après le Cours de Saussure, la linguistique en question (Carnets de l'Atelier de Sociolinguistique 1: Paris 2007), 13-80, at 25.
} 
The classical tradition of large migrations, ${ }^{11}$ combined with European colonial expansion during the Renaissance, ${ }^{12}$ are central ingredients in the dominant European model of language change until the mid-twentieth century. There are different ways, however, to account for the historical data. Speakers of a group of Indo-European dialects which contributed the basic morphological and phonological shape of Greek were probably established in the Aegean area by the late third millennium. We cannot know the numbers in which they arrived, but comparative evidence suggests that they could have been relatively few, rather than constituting a large migration which populated the region; there were certainly people already living in Greece and the islands (some of them may have been speaking dialects belonging to a different branch $^{13}$ of Indo-European), and the relatively high proportion of non-Indo-European and non-Greek lexicon in Greek suggests a period of cohabitation and bilingualism rather than rapid shift. ${ }^{14}$ If this model is at least

${ }^{11}$ These models can be seen in ancient Greek sources from Herodotus to Strabo, which regularly explain language change (and the emergence of a new ethnic consciousness) by reference to the movement of a large population into a region (e.g. Hdt. 1.56-57, Thuc. 1. 12, Strabo 8.1.2). There is nuance in the ancient sources, however: they also invoke language contact as a cause of change, and Herodotus in discussing the language of the Sauromatae (4.114-17), which is a peculiar type of Scythian, explains that the Amazons learned it imperfectly (and by implication passed on a modified version to their children). Imperfect learning is advanced as a cause of linguistic change in contexts of language shift by S.G. Thomason and T. Kaufman, Language Contact, Creolization, and Genetic Linguistics (Berkeley 1988) at 38, and others.

${ }^{12}$ The departure of Columbus for the New World was framed by the first Latin edition of Herodotus in 1474 (Venice, Jacobus Rubeus), and the first Greek edition in 1502 (Venice, Aldus).

${ }^{13}$ Anatolian is most often suggested: see M. Finkelberg, Greeks and Pre-Greeks. Aegean Prehistory and Greek Heroic Tradition (Cambridge 2005), 42-54 for arguments.

${ }^{14}$ See S.G. Thomason, Language Contact : an Introduction (Edinburgh 2001), 129 for the distinction between borrowing and shift-induced interference, a distinction which 'correlates robustly with linguistic effects: non-basic vocabulary first and most in borrowing, with 
partly correct, it also suggests that the indigenous culture held some prestige in the eyes (and ears) of the newcomers (whereas in contact linguistics a 'substrate' language is often associated with a culture relatively lacking in prestige in the contact situation).

The new arrivals contributed a distinct linguistic ingredient which penetrated more or less the entire region; the historical results of this coproduction we know collectively as Greek. There are parallels later in European history, of course, for a change in language associated with a new population group. It is striking, however, that social and linguistic processes in cases well within the historical period - the emergence of Old English in the wake of Anglo-Saxon settlement in Britain following the Roman-British collapse of the midfifth century C.E., or the development of Spanish in the Iberian peninsula - have been equally disputed, which suggests that models may be partly to blame (rather than simply a lack of data, which of course is always a problem). In the case of both English and Spanish, the question 'How did it arrive?' is confusingly mixed up with the history of treating the terms English and Spanish as a given, rather than a social and historical construct (which refer, of course, to the standard language in both cases). In the cases of both old English and Iberian Latin, immigrants speaking closely related idioms arrived over an extended period, from different regions, and encountered a range of local languages where they settled. They clearly exercised political and military power, and had cultural weight, though they are likely to have been well outnumbered by the existing population. The linguistic standards which emerged were not the result of linear development from a proto-language spoken by the putative genetic ancestors and brought from overseas; each represents 'a

structure and basic vocabulary borrowed later if at all; phonology and syntax most prominent in shift-induced interference, with lexical transfer lagging behind or absent altogether. One implication of this distinction is that it permits an educated guess about the type of contact that was responsible for contact-induced changes in a long-vanished contact situation'. 
discursively constructed political artifact ${ }^{15}$ which prevailed after a chaotic history of political struggle and cultural influence. ${ }^{16}$ They forced regional and social competitors into the status of dialects or patois.

The historical details vary, but it is characteristic for a standard language, an artificial compromise of a dialect of power with a written chancellery standard, and unnatural in the sense that at times it may have had few or no native speakers, to create a non-authentic standing for the non-written varieties. Modern standard German had no native speakers before the end of the eighteenth century, but - in a result quite at odds with received ideas of the lifeless 'artificial' language - rose to a status where it dominated the German dialects, many of which disappeared before it. It also sucked in neighbouring related languages (i.e. reassigning them as dialects of German rather than independent languages). ${ }^{17}$ The term Hochdeutsch, High German, transformed itself from a descriptive regional term (the uplands of southern Germany, as opposed to Niederdeutsch) into an

${ }^{15}$ J. Del Valle, 'Language, politics and history', in id. (ed.), A Political History of Spanish (Cambridge 2013), 3-20, at 18.

${ }^{16}$ E. Pulgram, 'The nature and use of proto-languages', Lingua 10, 18-37, at 29: 'Instead it seems highly probable and reasonable ... not that Latin was imported in the Iberian peninsula and there existed for a while in a modified form called Proto-Ibero-Romanic before it was somehow decomposed into various dialects, but that Latin (and very likely not just one kind of local or social dialect of Latin, nor one Latin of a single period) was superimposed upon, and exposed to the substratic influence of, a variety of already existing dialects ... That is to say, there never were any people to whom Proto-Ibero-Romanic was a native language.' See also Pulgram 'Spoken and Written Latin', Language 26 (1950), 458-466 on 'vulgar Latin'; and R. Wright, Late Latin and Early Romance in Spain and Carolingian France (Liverpool 1982), chapter 3 'Carolingian France: The Invention of Medieval Latin.'

${ }^{17}$ What H. Kloss, in a fundamental study of the notion of dialect and Dachsprache, called the 'near-dialectization of a sister language': 'Abstand languages and Ausbau languages', Anthropological Linguistics 9 (1967), 29-41. 
evaluative metaphorical term. ${ }^{18}$ Standard languages have been described as "pathological in their lack of diversity'; ${ }^{19}$ the ancient Greek situation was a little more complex. Apart from the fact that Greek was a pluricentric language with independent regional standards, there emerged a number of supraregional linguistic codes which were associated with high literature. A polity such as classical Athens did, therefore, allow a number of linguistic standards. It accepted at least some Greek dialects as valid forms of Greek: Aristophanes brings characters on stage speaking dialect (the rendition of the dialect is not parodic, despite the comic context), and certain types of poetry were produced in a form of Doric or Ionic.

The development of writing in Greece led to the evolution of a number of epigraphic standards, some of which were underpinned by a literary (prose) standard. With regional standards, and often radically different social and political structures across the Greek-speaking world, non-standard varieties (where they existed) must have been regional too. Even though the categories concerned were either universal (sex) or near universal (servile status), gender roles clearly differed from region to region in Greece, and so did the range of social and political statuses (slaves, serfs, metics and citizens) in the context of different notions of citizenship.

\footnotetext{
18 'Outside linguistics, the term has ... undergone a reinterpretation from a geographic characterisation to a qualitative ranking: in general usage, Hochdeutsch is commonly understood to refer to a "higher" form of language, a culturally elevated Hochsprache "High language" superior to other forms of German. This reinterpretation establishes a particularly powerful case of standard language ideology'. H. Wiese, ' “This migrants' babble is not a German dialect!" The interaction of standard language ideology and "us"/"them" dichotomies in the public discourse on a multiethnolect', Language in Society 44 (2015), 341-368, at 345-6.

${ }^{19}$ R.A. Hudson, Sociolinguistics (Cambridge 1980), at 34.
} 
3. Detailed analysis of social varieties of language is associated with the growth of sociolinguistics after the Second World War, and the study of language in its political and social context: W. Labov's The Social Stratification of English in New York City (Washington 1966) is widely regarded as the pioneering work in the new field. New recording techniques allowed researchers to identify variables in the speech of individuals, and to quantify them accurately. For the first time it was understood that linguistic variation is not random, but structured, and that language change in a community grows out of synchronic variation.

A language can be thought of as a number of overlapping varieties, some of which are tied to region, others to social group, gender, and age, and almost all to a combination of these. Conversely, a speaker is not a member of a single social group or linguistic community: speakers belong to social networks, and research has indicated that examining the nature and extent of the networks that a speaker forms part of can provide better explanations of the social and linguistic data than simple variables such as gender or social class considered separately. ${ }^{20}$ In addition, most speakers command a range of linguistic registers tied to the nature and formality of the setting, the interlocutors, and the content of the utterance. Such registers are likely to include elements from different social varieties. Clearly we do not have access to this range of material in investigating social dialects in the ancient world, and most of our data comes from Attica. ${ }^{21}$

\footnotetext{
${ }^{20} \mathrm{~J}$. and L. Milroy (1993), 'Mechanisms of change in urban dialects: the role of class, social network and gender', International Journal of Applied Linguistics 3 (1993), 57-77.

${ }^{21}$ Papyri are a rich source of linguistic variation for Egyptian Greek from the Hellenistic period until the Arab invasions; in addition to diachronic development, variation can often be correlated with ethnicity, occupation, and socio-economic status. See M. Depauw and J. Stolk, 'Linguistic variation in Greek papyri: towards a new tool for quantitative study', GRBS 55 (2015), 196-220; T. Evans and D. Obbink (edd.), The Language of the Papyri (Oxford 2010).
} 
4. The social stratification of Attica cannot easily be compared with that of the industrialized nation states in which much modern sociolinguistic research has been carried out. We shall concentrate on the central period for which we have evidence of the epichoric dialects (the sixth to the fourth centuries B.C.E.); in the centuries before and after this period the social structure of the region must have been rather different. In the citizen body social stratification was no doubt less extreme than in many modern political communities: nevertheless, there were clearly marked differences in wealth, education and prestige. In classical literature there is certainly evidence for snobbishness within the citizen body based on family, education and wealth. Male citizens comprised a small percentage of the population of Attica, a figure which is notoriously difficult to estimate (and the population seems to have declined in the fourth century). Most estimates ${ }^{22}$ put the number of male citizens in the range $35,000-45,000$, and then quadruple that figure to take account of women and children. To this one has to add slaves (perhaps as many as 100,000) and metics (estimated at 25,000-30,000): this gives a total population approaching 300,000, of which the male citizens formed around $10 \%$ or slightly higher. Even this restricted group cannot have been linguistically homogeneous, since it will have included (amongst others) the following large groups: i) small-holders working their land in rural locations across Attica, $i$ ) the wealthy urban elite, and iii) the urban poor (the thete class, who served in the navy). ${ }^{23}$ In an urban context the social networks will have been considerably more complex than such broad groupings suggest.

${ }^{22}$ R. Osborne, Demos: the Discovery of Classical Attika (Cambridge 1985), 42; M.H. Hansen, The Athenian Democracy in the Age of Demosthenes (Oxford), 93; with id., Studies in the Population of Aigina, Athens and Eretria (Copenhagen 2006).

${ }^{23}$ I take the term thes (with hippeis 'cavalry' and zeugitai 'hoplite class') to reflect not a Solonic property assessment, but an index of current economic capability. See de G.E.M. de Ste. Croix, 'The Solonian census classes and the qualifications for cavalry and hoplite service', in D. Harvey and R. Parker (edd.), Athenian Democratic Origins and Other Essays by 
5. Evidence for linguistic variation associated with different sections of the population is scarce, since our two main sources, literature and inscriptions on stone, are themselves associated with very specific linguistic registers. High literature (which includes tragedy, and the historical prose of Thucydides) is written in a special literary dialect, influenced by 'foreign' genres such as Ionic prose, and epic and lyric poetry. The prose of fourth-century speech-writers, on the other hand, who wrote for delivery in the law courts or political arenas such as the popular assembly, is designed to be an unadorned approximation to the educated speech of citizen jurors or voters. It is not poetic, and generally avoids overt stylization (especially the law-court speeches), and to that extent can give us an idea of what was considered suitable in a formal register of the highest social group. Comedy is an important source to which we shall return: the language of comic dialogue, like forensic prose, is clearly designed to sound close to (a high variety of) spoken Attic, even though it is written in verse, which means that some dialect features (for example, the 'Ionic' dative plurals in $-\alpha(\sigma \mathrm{l} /-\mathrm{ol \sigma l})$ are used merely for metrical convenience. Unfortunately for us, though comic playwrights imitate and poke fun at a variety of linguistic phenomena, they avoid mocking social dialects of Attic which sections of their citizen audience are likely to have used.

Inscriptions are generally written in a formal variety of Attic which is not identical to literary prose, but is nevertheless rather uniform and clearly not a close reflection of the vernacular, since it seems deliberately conservative in some respects. ${ }^{24}$ This 'chancery'

G.E.M. de Ste. Croix (Oxford 2004), 46-56; H. Van Wees, 'The myth of the middle-class army: military and social status in ancient Athens', in T. Bekker-Nielsen and L. Hannestad (edd.), War as a Cultural and Social Force: Essays on Warfare in Antiquity (Copenhagen 2001), 45-71.

${ }^{24}$ E.g. the innovative dative plural - $\alpha 1 \zeta$ of the first declension was suppressed until the 420s: see K.J. Dover, 'The language of Classical Attic documentary inscriptions', TPhS 79 (1981), 114, repr. in Greek and the Greeks (Collected Papers vol. i, Oxford 1987), 31-41. 
language is characteristic of public (official) inscriptions; most inscriptions of any length that were put up by private individuals, but intended for public consumption, are written in verse (epitaphs, dedications), and the language is a mixture of Attic and epic/elegiac literary dialect. For evidence of the way non-elite social groups spoke we rely on 'informal' epigraphic texts such as graffiti (incised on ceramic material), dipinti (painted on ceramics), ostraka, and curse tablets (scratched on lead). These sources may give us glimpses of vernacular Attic, but the very fact of being written makes them uncertain evidence, since $a$ ) the writer must have had access to a reasonable degree of education, and b) spelling conventions always disguise the writer's vernacular to some extent.

These informal texts are often carelessly spelled and written, and it is sometimes hard to be sure how much weight to attach to spellings which appear to anticipate later developments (since some of the spellings mistakes are clearly random). However, by around 400 B.C.E. at the latest there is sufficient evidence pointing to non-elite dialect in Attica which in most (but not all) respects anticipated the later development of the elite standard; this variety (in reality a range of varieties) reflected some of the developments that were taking place in neighbouring Boeotia. It is worth noting that we are unlikely to be dealing with a simple High $\rightarrow$ Low continuum; in most speech communities the non-elite dialects are the most innovative varieties, and there are (therefore) a number of competing variants at this level (a model of social dialects will be pyramid-shaped). A characteristic of elite language is that it is conservative: innovative features are typically suppressed.

The spelling of informal texts suggests the following: ${ }^{25}$

\footnotetext{
${ }^{25}$ For the convenience of readers, and in the interests of balance, references are given to appropriate sections of both L. Threatte, The Grammar of the Attic Inscriptions $i$ : Phonology (Berlin 1980) and S.-T. Teodorsson, The Phonemic System of the Attic Dialect 400-340 BC (Göteborg 1974). Threatte's grammar does not, on the whole, concern itself with
} 


\subsection{Vowels}

a) The diphthong [ei] merged with the long close vowel [e:], in some social dialects perhaps as early as the sixth century, and in most varieties by the last quarter of the fifth century; in some varieties [ei] must have merged swiftly with [i:] (see below). The parallel change [ou] > [o:] and [u:] spread more slowly than [ei] > [e:] and [i:], but seems to have been achieved by the end of the fifth century (Teodorsson Phonemic System 291, Threatte GAI 239). ${ }^{26}$

b) The simplification of the over-crowded front vowel system ('itacism') started early: in

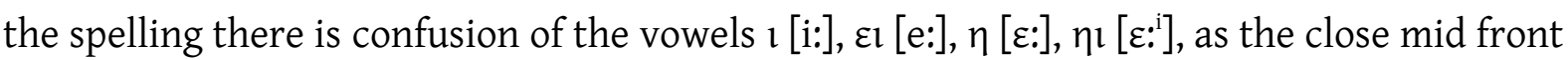
[e:] moved towards [i:], and the open mid front [ع:] moved towards [e:] and then [i:].

E.g. óróбol ỉóv in a curse tablet, ca. 400 (Teodorsson Phonemic System 76, 176, Threatte GAI 196); $\Theta \rho \alpha \sigma u k \lambda \eta \imath$ (for $\Theta \rho \alpha \sigma u k \lambda \varepsilon \tilde{\imath}$ ) in letter on lead, ca. 400 (Teodorsson Phonemic System 94, 188, Threatte GAI 356).

It seems likely that a concomitant development in some non-elite varieties was the fading of vowel length as a distinctive feature (distinctions such as $[\mathrm{i}] \sim[\mathrm{i}:])$.

c) Informal texts also show some uncertainty between the spelling $\alpha$ and $\alpha$, which suggests that the diphthong $\alpha \mathrm{l}$ had in some sections of the population started the process of

'substandard' Attic, and he is suspicious of the early dating of sound changes which are traditionally associated with the koine.

${ }^{26}$ When the old diphthongs [ei, ou] became long close vowels [e:, o:], they merged with existing long close [e:, o:] which were the result of contraction and compensatory lengthening. As a result the spellings EI and OY came to be used for all of these vowels: thus

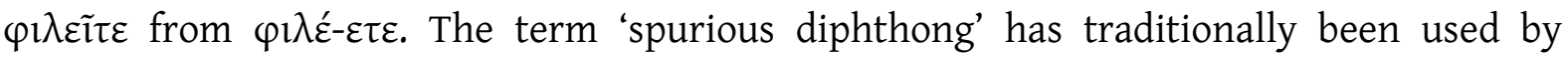
classicists for this digraph spelling. Synchronically, of course, the Athenians would have had no idea whether the sound written EI or OY had been a real diphthong or not. Close [e] was approximately the vowels in French été, close [o] as in French mot. 
monophthongisation [ai] $>[æ]$ and later $[\varepsilon]$ (as in Boeotia, and in the koine): for example, spellings $\pi \alpha \zeta$ for $\pi \alpha \tilde{i} \zeta$ on eight Attic vases (late sixth and fifth centuries) from Immerwahr's corpus (Teodorsson Phonemic System 99, 197, Threatte GAI 268). ${ }^{27}$ In Boeotia the diphthong or [oi] had also started to monophthongize at this period, to [œ] / [ø] (approx. German schön), then [y], and finally to [i]. Evidence for this in Attica is scarcer and later than for [ai]: spelling alternations (e.g. confusion between o and ol) are mostly from the fourth century (Teodorsson Phonemic System 202-5, Threatte GAI 333).

\subsection{Consonants}

a) There is evidence for lenition of the plosive $\gamma[g]$ in some contexts in disfavoured speech styles. A fragment of the comic playwright Plato (Hyperbolus, PCG 183) quotes a character attacking the speech of an unnamed person as 'unAttic':

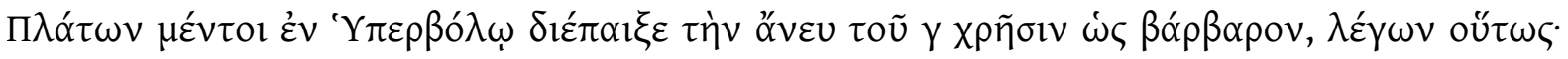

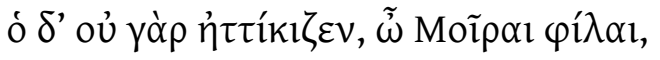

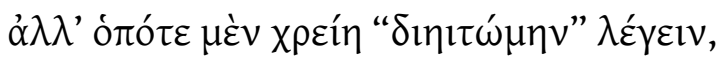

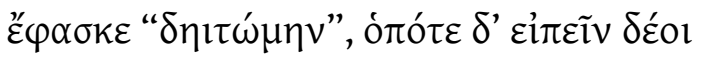

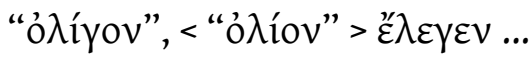

'Plato, however, in his Hyperbolus mocked the dropping of $g$ as barbarous, as follows: "He didn't speak Attic, ye gods, but whenever he had to say diētōmèn he said dètōmèn [?dze:to:me:n], and when he had to say oligos he came out with olios [?oliyos] ..."'

\footnotetext{
${ }^{27}$ Immerwahr's corpus numbers 934, 1075, 2620, 4472, 5592, 6149, 6720, 8100 (a couple of these may be miswritten rather than significant): H. Immerwahr, Corpus of Attic Vase Inscriptions (PDF available online: version dated January 2009).
} 
The person whose slack phonology is being attacked is almost certainly Hyperbolus himself, since it is remarkable that the only Athenians whose speech habits are attacked in Old Comedy are politicians - even though the two features in question are likely to have been widely heard in sections of the population. ${ }^{28}$ Since they could be characterized as the result of an attempt to minimize the effort of articulation, it is easy to see that they might be stigmatized in a conservative dialect. For < ỏ $\lambda i ́ o v>$ we assume a development familiar

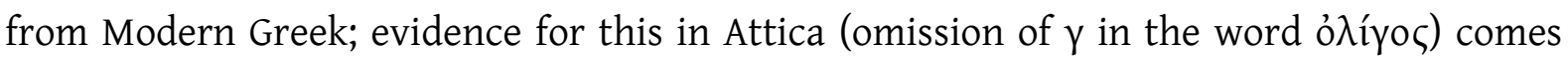
from both stone and informal inscriptions, starting in the fourth century (Teodorsson Phonemic System 225, Threatte GAI 440). In the case of $\delta ı \imath \tau \omega ́ \mu \eta \nu$, if the [i] lost syllabicity and was compressed into a palatal glide [j], palatalization of the preceding [d] may have produced a sound approaching an alveolar affricate at the beginning of the word (cf. Italian giorno < Latin diurnum). There are two issues here: firstly, the passage [i] > [j] (synizesis), and secondly, an effect exercised by [j] on a preceding consonant. Neither is easy to represent graphically: the omission of 1 in this context is rare in Attic inscriptions (Threatte GAI 393), and there are few if any examples of the graphic representation of any effect on a preceding consonant from Attica or Boeotia (unlike Thessaly, where deletion of 1 and doubling of the consonant is common). ${ }^{29}$ But recent work has suggested that the synizesis of $[\mathrm{i}]$ and $[\mathrm{e}]$ in the position $\mathrm{C}_{-} \mathrm{V}$ was probably widespread in vernacular Attic and Boeotian, and in other dialects across the Greek world. ${ }^{30}$ Synizesis and palatalization are clearly

\footnotetext{
${ }^{28}$ See S. Colvin, 'The language of non-Athenians in Old Comedy', in D. Harvey \& J. Wilkins (edd.), The Rivals of Aristophanes (London 2000), 285-98, at 288-91; and A.C. Cassio, 'Attico “volgare" e Ioni in Atene alla fine del 5 secolo AC', Annali Ist. Orient. Napoli 3 (1981), 79-93.

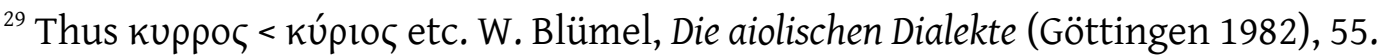

${ }^{30}$ See J. Méndez Dosuna, 'El cambio de $<\varepsilon>$ en $<1>$ ante vocal en los dialectos griegos', in E. Crespo et al. (edd.), Dialectologica Graeca: Actas del II Coloquio Internacional de Dialectología Griega (Madrid 1993), 237-59, with additional bibliography.
} 
attested in Mycenaean: e.g. di-pte-ra $a_{3}-z a$ /diphtherā aidzāa/ 'goat skin', where $a_{3}-z a$ represents the development of *aigyā from *aigiā or *aigeā (PY Ub 1318).

b) The pronunciation of the letter $\zeta$ across the Greek world has always been a problem in Greek phonology. The modern consensus is that in standard Attic of the early Classical period the letter represents [zd]. Over the course of the fourth century spelling fluctuations

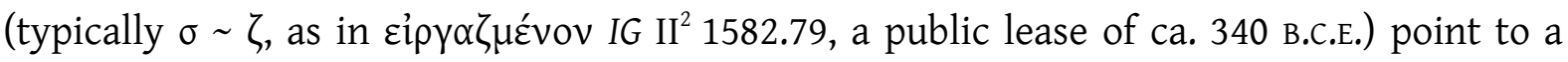
change [zd] > [z] (Teodorsson Phonemic System 225-7, Threatte GAI 546-9). It is hard to say when this change started, and how widespread it was, but a remark by Dionysius of Halicarnassos suggests that the sound $[\mathrm{zd}]$ was a high status variant in the post-classical period:

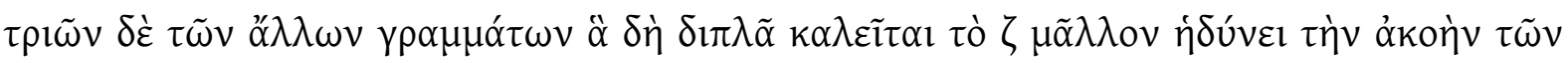

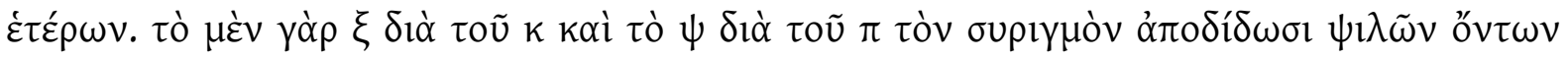

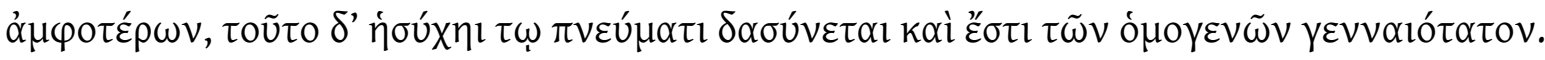
'Of the three other letters which are called double the $\zeta$ pleases the ear more than the rest. For the $\xi$ and the $\psi$ give off a whistling sound (because they contain $\kappa$ and $\pi$ respectively, and are voiceless), whereas $\zeta$ has a pleasant voiced quality and is the noblest of this series.' (De compositione verborum 14)

There is also evidence for a variant $[\mathrm{d}] /[\mathrm{dd}]$ in Attica as early as the first quarter of the fifth century; this variant is an isogloss with Boeotian. An ostrakon from the Kerameikos (perhaps 471 B.C.E.) $)^{31}$ bears the inscription

\footnotetext{
${ }^{31}$ S. Brenne, 'Ostraka and the process of ostrakophoria', in W. Coulson (ed.), The Archaeology of Athens and Attica under the Democracy (Oxford 1994), 13-24, at 21; id., 'Die Ostraka (487-ca. 416 v. Chr.) als Testimonien', in P. Siewert (ed.), Ostrakismos-Testimonien I (Stuttgart 2002),
} 


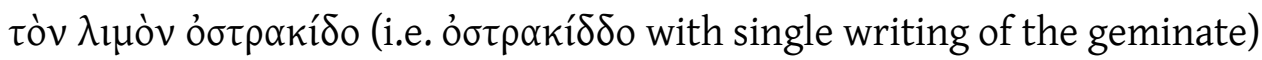
'I ostracise hunger'

This is highly unlikely to be a high-status variant: the writer seems to be complaining that the feuding of the elite which led to ostracism votes is irrelevant to the needs of the majority of the citizens. There are two other instances of this variant in informal inscriptions from Attica:

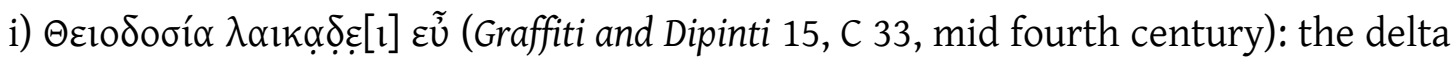
is broken, but is clearly a delta. 'Theodosia fellates skilfully.'

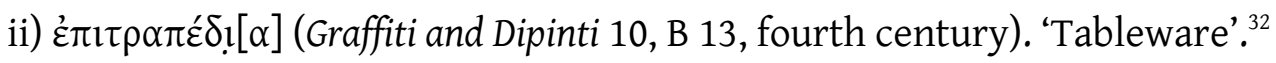

In all of these cases there is an appropriate match between subject matter and linguistic register. A social variety that shared this isogloss with Boeotian is likely to have had its origins in a north-eastern region of Attica: there is evidence for the feature in Megarian also (the Megarian in Aristophanes' Acharnians uses it). In the ostrakon above it may be significant that the $\sigma$ is a correction of a $\tau$, since an assimilation of $\sigma \tau$ to $\tau \tau$ seems to have been a feature of varieties of spoken Boeotian that the Athenians were familiar with: cf. the

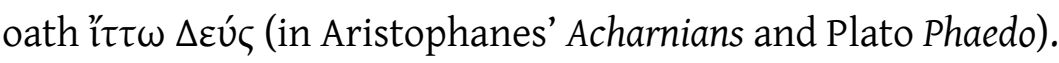

c) The single writing of geminate consonants is common on vases, curse tablets, ostraka and private inscriptions from the fifth century (occasionally also in public inscriptions). The practice of writing geminate consonants was established only in the early fifth century, so some variation is to be expected; ${ }^{33}$ but the number and the distribution points to the

36-166, at 97, no. T 1/79. Discussed in S. Colvin, 'Social Dialect in Attica', in J. H. W. Penney (ed.), Indo-European Perspectives. Studies in Honour of Anna Morpurgo Davies (Oxford 2004), 95108.

${ }^{32}$ M. Lang, Graffiti and Dipinti (Athenian Agora 21: Princeton 1976).

${ }^{33}$ M. Lang, Ostraka (Athenian Agora 15: Princeton 1990), at 14-15. 
phonetic simplification of geminates in some non-elite varieties by the end of the fifth century (Teodorsson Phonemic System 231-5, Threatte GAI 513-25).

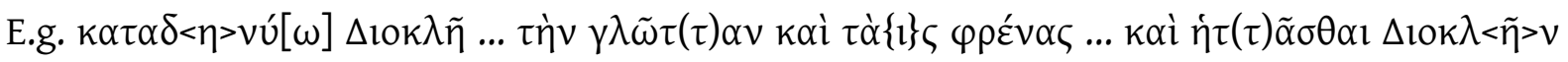
$\dot{\alpha}^{\prime} \pi^{\prime} \dot{\varepsilon} \mu \mathrm{o}(\tilde{v}) \dot{\varepsilon} v \pi \alpha v \tau \grave{~} \delta 1 \kappa \alpha \sigma \tau<\eta>\rho i ́ \omega l$

'I bind Diokles ... his tongue and his mind ... and let Diokles be defeated by me in every lawcourt' (Wünsch IG III App. 94, fourth century)

6. We have considered some of the evidence for non-elite or 'substandard' varieties of Attic; speakers belonging to the political and literary elite probably maintained a conservative pronunciation - at least in formal registers - until considerably later (see $\S 7.1$ below). The difference between urban and rural environments must also have been an important factor, and will have intersected with other variables such as the degree of education; even after the end of formal education, there will have been ongoing differences in exposure to literary texts and performances, and to new philosophical and sophistic theories about language. A distinction which cuts across these categories is articulated in a fragment of Aristophanes (PCG 706), preserved in Sextus Empiricus:

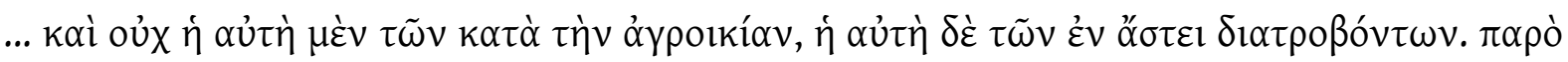

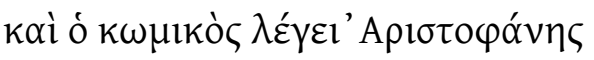

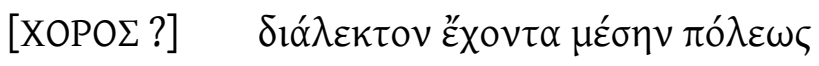

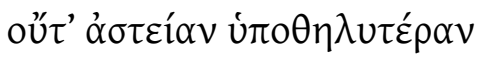

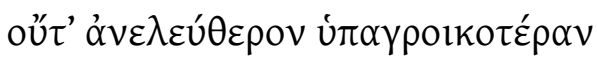

'[the grammarians say that] ... the idiom of those who live in rural areas is different from that of city dwellers. Concerning which Aristophanes the comic poet says: "[his] language is the normal dialect of the city - not the effeminate high-society accent, nor uneducated, rustic talk"' 
For an idea of this 'effeminate' urban speech style, we can turn to Aristophanes' Knights

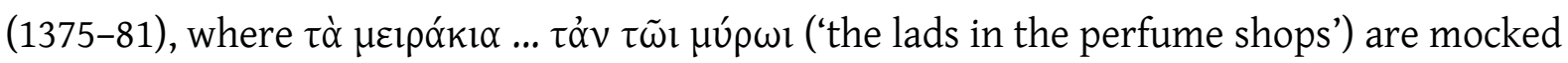
for an affected Ionicizing style, in particular the use of adjectives in -1kóc. The comic poets seem careful to avoid mocking 'uneducated, rustic talk'; the nearest Aristophanes comes to this is in the linguistic characterization of some of his 'anti-hero' old men, whose speech may be marked by parataxis (Strepsiades, Philocleon, Euelpides). When the linguistic defects of politicians are attacked, these are characterized as 'barbarian' ${ }^{34}$ In a play called Cleophon, Plato Comicus portrayed the politician's mother speaking broken Greek to him

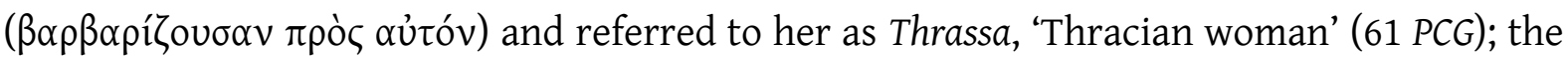
chorus at Ar. Frogs 679-84 makes the same connection between Cleophon's diction and alleged barbarian roots. ${ }^{35}$

A sour comment on Athenian speech habits in the Classical period survives in the Constitution of the Athenians of the 'Old Oligarch'. The writer implies that Athenian naval supremacy has been responsible for a range of decadent behaviours, and in particular:

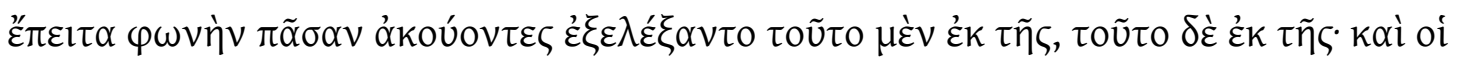

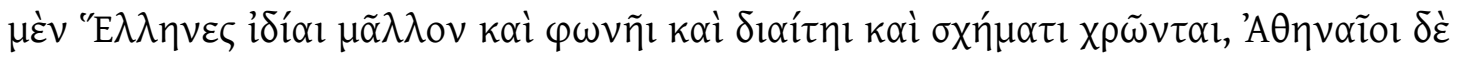

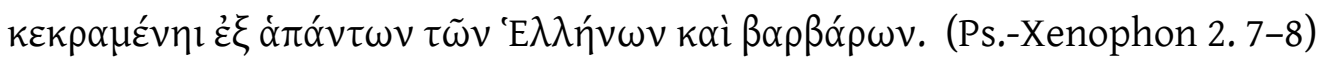

\footnotetext{
${ }^{34}$ As Greek linguistic culture moved from koine to Atticism in the imperial period, elements of vernacular Greek were regularly stigmatised as barbarismos or soloikismos (from Soloi in Cilicia).

${ }^{35} \mathrm{C}$. Brixhe has shown that many of the 'barbarisms' uttered by foreigners in Aristophanes were also (innovative) features of non-standard Greek: 'La langue de l'étranger non grec chez Aristophane', in R. Lonis (ed.) L'étranger dans le monde grec (Nancy 1988), 113-38; 'Les “ardoises” de l'Académie. Histoire exemplaire d'un dossier délicat', in L. Dubois and E. Masson (edd.), Philokypros (Minos suppl. 16, Salamanca 2000), 61-89 at 83-86.
} 
'Further, hearing every type of language, they have taken one feature from here, another feature from there. Greeks on the whole use their own language, customs and dress; but the Athenians use a mixed bag taken from all the Greeks and barbarians.'

This comment is interesting, since it points to a variety of Attic which we would want to posit on other grounds: an expanded variety, influenced by Ionic, and associated particularly with mercantile activity and the navy. This 'Piraeus Attic' will have been a nonelite variety, perhaps marked by many of the phonological changes outlined above; it must also have been a precursor of the spoken koine in the Hellenistic period. (The Greek of Xenophon, an upper-class Athenian who spent much of his life in a military context and outside of Attica, is marked by a number of lexical items that are alien to Attic.)

Metics and slaves will also have had an input into non-elite vernacular. Athens was, by ancient Greek standards, a relatively open city to foreigner workers and residents, and slaves (many of whom will have originated from outside Attica) formed a large proportion of the population. The linguistic influence of slaves should not be understimated, since they played an important role in the upbringing of the young citizen (nurses, paidagogoi, and others). In the last decades of the fifth century the rural population of Attica was often, owing to the Peloponnesian war, crowded inside the walls of Athens. This is likely to have played a role in the spread of non-conservative variants; and explains why it would have been invidious for comic playwrights, in the context of domestic hardship and foreign enemies, to make non-elite or non-urban variants the subject of jokes. 
7. Gender is one of the central variables in most, perhaps all, linguistic communities. ${ }^{36}$ There are often marked differences in phonology, lexicon and idiom; differences in morphology and syntax have also been noted. It is very difficult to assess the effect of gender on language in ancient Greek, for the simple reason that we have almost no written sources by women, and very little reference to female speech in male writers.

Comedy, our principal source for the representation of everyday language, gives no suggestion of phonological differences between male and female characters. There is, however, a range of distinctive oaths, expletives, and forms of address that are put into the mouths of women; certain lexical items also seem disproportionately frequent in female characters, and this includes a genitive of the personal pronoun which could be classified as an innovative morphological feature.$^{37}$ Forms of address in male-female interactions, as opposed to same-sex interactions, tell us more about social relations between the sexes in Athens than about language stricto sensu, and the same is true of the observation that women avoid obscene language in the presence of men. However, all of this information contributes to a wider picture of the ethnography of language in a community. Analysis of oaths and expletives reveals some lexical differences between stage characters. A study by

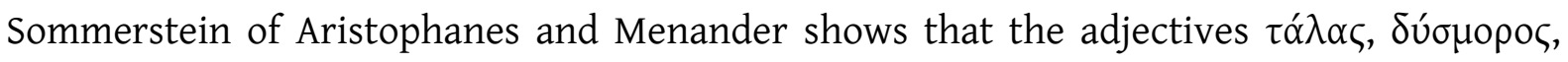

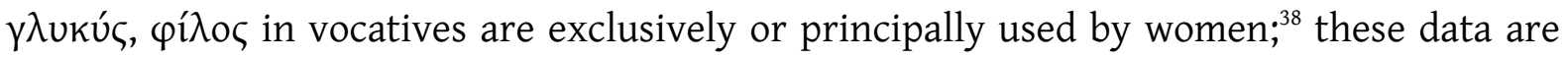
likely to be skewed by a male view that women's language was more emotional, or less serious, than men's language (in this connection Sommerstein points out that $\varphi$ ílos as an

\footnotetext{
${ }^{36}$ See P. Trudgill, Sociolinguistics: an Introduction to Language and Society (Penguin 2001 ${ }^{4}$ ), 6180 for an overview; and M. Dunn, 'Gender determined dialect variation', in G. G. Corbett (ed.), The Expression of Gender (Berlin 2014), 39-68.

${ }^{37}$ A. Willi, The Languages of Aristophanes (Oxford 2003), 161-96; and see further below.

${ }^{38}$ A.H. Sommerstein, ‘The language of Athenian women', in id. and F. De Martino (edd.), Lo spettacolo delle voci (Bari 1995), ii. 61-85; repr. in Talking about Laughter (Oxford 2009), 1-14.
} 
address is common between men in Plato's dialogues). As Euripides has Megara say in Euripides' Herakles (536):

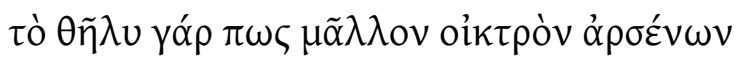

'I suppose that women are more emotional than men'

Many lament expletives in tragedy (oì ' $\gamma \omega$ ' and others) are exclusively female; as Mcclure notes, '... many of the expressions associated with women signify a state of heightened pathos' ${ }^{39}$ Specialized lament vocabulary also recalls a specific social practice (perhaps the only one) in which women's voices were allowed, namely ritualized mourning for the dead. For the most part our sources are explicit that women were expected to remain silent.

Two further points in Megara's utterance are worth noting. Firstly, she has prefaced the line with an apology: despite the fact that the entire family is about to be slaughtered, she apologizes to her father-in-law for speaking before him, which 'is his right'. Secondly, the line contains the softening particle $\pi \omega \varsigma$. Analysis of the particle usage of female characters provides some evidence of 'hedging', a feature that linguists have identified in women's speech in many modern communities in which women are disempowered. It is described by Lakoff as follows: 'These sentence types provide a means whereby a speaker can avoid committing himself, and thereby avoid coming into conflict with the addressee ... The more particles in a sentence that reinforce the notion that it is a request, rather than an order, the politer the result'. ${ }^{40}$ Although our data are meagre, Sommerstein has identified a tendency to use concessive particles ( $\dot{\alpha} \lambda \lambda^{\prime}$ o $\tilde{v} v$, k $\alpha$ ítol, and clusters with $\left.\gamma \varepsilon\right)$, and Duhoux suggests a higher use of $\tau o l$ (collaborative) and $\varepsilon i$ than for male characters. ${ }^{41}$

${ }^{39}$ L.K. McClure, 'Female speech and characterization in Euripides', in A.H. Sommerstein and F. De Martino (edd.), Lo spettacolo delle voci (Bari 1995), ii. 35-59.

${ }^{40}$ R. Lakoff, 'Language and Woman's Place', Language in Society 2 (1973), 45-80, at 55-6.

${ }^{41}$ Y. Duhoux, 'Langage de femmes et d'hommes en grec ancien: l'exemple de Lysistrata', in J.H.W. Penney (ed.), Indo-European Perspectives: Studies in Honour of Anna Morpurgo Davies (Oxford 2004), 131-45, at 140. See also Willi (n. 37), 176-95 for analysis of comic data. 
In a much-discussed passage in Plato's Cratylos (418b-e), Socrates comments on changes in Greek phonology:

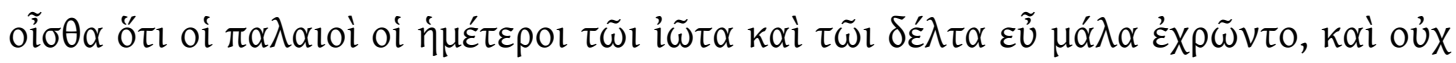

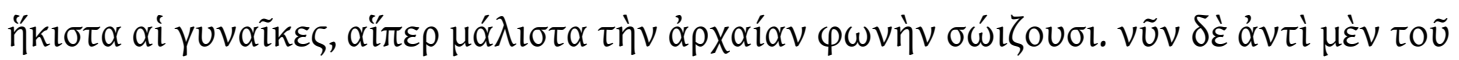

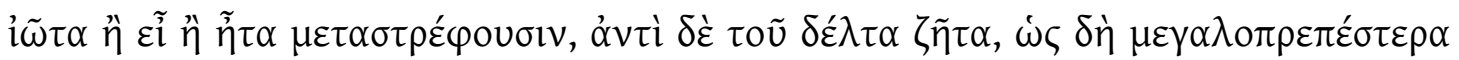

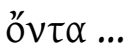

'You know that our ancestors made good use of iota and delta, and not least the women, who are especially liable to preserve the old way of speaking. But now people change [or: they change, viz. women] iota into epsilon or eta, and delta into zeta, because they are supposed to sound grander ...'

Some commentators have quoted alleged parallels from modern cultures, since in the early days of sociolinguistics some studies concluded that women tend to use a more conservative linguistic variety than men (closer to the prestige variety). ${ }^{42}$ These studies

\footnotetext{
${ }^{42}$ Classical scholars sometimes compare Cicero De Oratore 3.12.45: Equidem cum audio socrum meam Laeliam - facilius enim mulieres incorruptam antiquitatem conservant, quod multorum sermonis expertes ea tenent semper, quae prima didicerunt -, sed eam sic audio, ut Plautum mihi aut Naevium videar audire; sono ipso vocis ita recto et simplici est, ut nihil ostentationis aut imitationis afferre videatur; ex quo sic locutum esse eius patrem iudico, sic maiores. 'For my part, when I hear my mother-in-law Laelia (for it is easier for women to preserve uncorrupted [the language of] antiquity, because, by keeping less company than men, they always preserve what they first learned) - when I hear her I have the impression that I am hearing Plautus or Naevius: the sound of her voice is so correct and unaffected that she appears quite devoid of ostentation or affectation; from which I conclude that her father spoke in the same way, and her ancestors.' This tells us about Roman ideas on the role of women as safeguarders of purity, tradition and the Roman family, but not whether the Latin of aristocratic women in Rome was regularly marked by conservative linguistic features; especially as archaic Latin was less standardised that the classical language, and presents features that are
} 
tended to explain sex differentiation in language in terms of socio-economic class: women, feeling less secure than men for social and political reasons, associate themselves linguistically with a higher social group. Modern sociolinguistic work has questioned this implicit ranking of class over gender: in many contexts women are likely to create prestige forms rather than merely adopting them. ${ }^{43}$ Given the social networks that women in Athens participated in, there is no reason to predict that they would have favoured conservative speech styles, and some reason for thinking the opposite. They had minimal access to education, perhaps the most important agent in linguistic conservatism. ${ }^{44}$ Even if they were not legally barred from the theatre, it seems unlikely that large numbers of citizen women will have been in attendance; they were certainly excluded from the political and legal institutions where power derived from the manipulation of language. The day-to-day interactions of aristocratic women would have been largely with slaves, and the household may have been a locus of a sub-elite innovative variety (at a point in time which is hard to define boys in particular would have been exposed to a weak diglossia home language versus the public standard - which grew over time as the standard fossilized into the koine). Non-elite women were less likely to have been confined indoors, since many needed to work; in Aristophanes working-class women take their place

paradoxically 'innovative' compared to classical Latin (where they are suppressed, but reappear in post-classical Latin, or in informal inscriptions).

${ }^{43} \mathrm{~J}$. and L. Milroy (n. 20).

44 'A literate woman must have been the exception and not the rule', S.G. Cole, 'Could Greek women read and write?' Women's Studies 8 (1981), 129-155, at 135. M.P.J. Dillon makes a case that aristocratic female literacy may have been more widespread than previously assumed, in 'Engendering the scroll: girls' and women's literacy in classical Greece', in J. Evans Grubbs and T. Parkin (edd.), The Oxford Handbook of Childhood and Education in the Classical World (Oxford 2013), 396-417. 
alongside men in the market and are not to be messed with. ${ }^{45}$ There is clearly no reason to think that they would have used anything other than an innovative variety similar to the one spoken by their male counterparts.

If in the Cratylus passage above the implied subject of the sentence starting 'But now

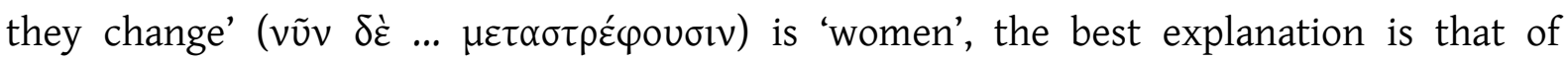
Sommerstein, who argues that that if women were indeed saying [i:] for [ $\varepsilon$ : $]$ and $[d]$ for [zd] then they spoke an innovative rather than a conservative variety: these features were shared with Boeotian. ${ }^{46}$ Willi has also argued that innovative features can be detected in the language of female characters on the comic stage: for example, in the use of the genitives $\mu \circ v / \sigma o v$ to indicate possession, and in the use of lexical items such as $\kappa \alpha \theta \alpha$ á $\varepsilon \rho$ 'like' and úró $\rho \chi \omega$ 'be'. ${ }^{47}$ If, as seems more natural, the verb 'they change' refers generally to contemporary speakers, then Plato is alleging an unexpected change of $[\mathrm{i}(:)]$ to $[\mathrm{e}(:)]$ and $[\varepsilon:]$, exactly the reverse of what we reconstruct. I interpret this as a straightforward reference to hypercorrection, whereby a speaker is unsure of, or cannot hear, the distinction between a prestigious and a non-prestigious variant: the speaker therefore overcompensates by using the prestige form where it is historically incorrect (the joke in Catullus 84: Arius says hinsidias instead of insidias). Plato argues, or pretends to, that [he:mera:] 'day' is a modern hypercorrect substitution for the ancient 'authentic' i $\mu \varepsilon \varepsilon_{\rho} \alpha$

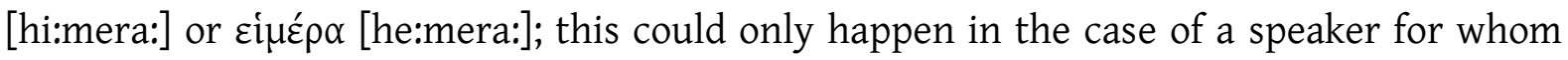
[e:] and [e:] had merged with [i(:)]. This enables him to make an etymological play with the verb i $\mu \varepsilon^{i} \rho \omega$ 'desire'. The argument is that women, being conservative, still say i $\mu \varepsilon \varepsilon_{\rho} \alpha$ [hi:mera:]; since this is, in fact, an innovative pronunciation, it would still be in line with Sommerstein's argument.

\footnotetext{
${ }^{45}$ So for example Wasps 492-99 (a woman gives a feisty response to a customer asking for free onions), Frogs 549-78 (the innkeeper threatens to smash Xanthias' teeth).

${ }^{46}$ Sommerstein (n. 38), at 83.

${ }^{47}$ Willi (n. 37), at 161-96.
} 
7.1 It is worth noticing that the obsession with mapping letters (eta, etc.) onto sounds presupposes, and flows from, two fifth-century spelling reforms: the use of the digraphs ('spurious diphthongs') EI, OY for [e:], [o:], and the adoption of the Ionic alphabet (official in 403 в.с.Е.) by which $\mathrm{H}$ was renamed eta and reassigned from [h] to inherited open [ع:]. Before the second half of the fifth century both long $e$ vowels were written E, and it would have been difficult for Plato to frame his argument in the Cratylos. The script reforms in late fifth-century Athens, in the context of Sophistic interest in defining and classifying language (orthoepeia, associated particularly with Protagoras and Prodikos), fed a phonographic revolution in Greek thought about language. Words were reimagined as a sequential ordering of discrete minimal elements (stoicheia), each of which contributed its correct pronunciation. This opened the way for a reading pronunciation of words, which was more correct as it captured an 'original' state of the word and its relationship with reality. This is a powerful prod to a linguistic culture to start reimagining language variants as correct or incorrect (rather than merely vulgar, or noble) and is a necessary ingredient in diglossia: the phonographic articulation of the prestige variety contrasts with the 'organic' production of the vernacular. This is how a classicizing pronunciation of highprestige or written Greek continued until, presumably, the time of Libanius (many of the grammatical categories of Attic would have been indistinguishable in the fifth century C.E. in the phonology of contemporary vernacular); it may even have been maintained as a primary speech style by some.

In any case, if hypercorrection is the right explanation of the Cratylos passage, it indicates that there was an awareness of sound change by the early/mid-fourth century in Athens, and a desire to undo it. ${ }^{48}$ This points to a new self-consciousness in the linguistic

\footnotetext{
${ }^{48}$ See S.-T. Teodorsson for a temporary reversal of the merging of certain front vowels in the fourth century: The Phonology of Attic in the Hellenistic Period (Göteborg 1978), 68, 92-94.
} 
culture of Athens: Attic now had value as a cultural and epistemic property, partly connected with its emergent status as the prevailing written form of Greek. If women or market-traders said [ni:ki:] for NIKH, this was to be explained by their of lack of ownership in the shared cultural heritage of the Greek world, in which Athens was the natural leader. At around the same time Isocrates was making an explicit connection between paideia and Greek identity, and saw the Attic dialect as playing a central role in this. ${ }^{49}$

8. Languages generally move in the direction of a 'substandard'; this is merely because languages change continuously, and the standard is a conservative variety which suppresses innovation, and is generally based on the written language and (usually) a literary canon. One cannot predict which of the competing non-standard elements will prevail to become part of the new standard; some will disappear, and others will remain in the non-standard varieties. But at a given point in time, all are part of the grammar of the linguistic community.

At the start of the fifth century in Athens there was no clear concept of grammaticality, since writing in prose was in its infancy. Over the next two centuries literacy increased and the book trade grew; language became an object of philosophical enquiry and rhetorical training, and prose as a genre became culturally central. By the end of the fourth century an Attic-based Panhellenic standard had emerged, and in Athens at least it became possible to compare ways of speaking with this standard; in this context a polar opposition between correct and improper language established itself in the social consciousness of Greek speakers (and then Latin speakers). Linguistic heterogeneity is reduced to a simple dichotomy, and this is a familiar strand in European thought about language. Popular or colloquial language is given the same status as standard language or regional dialect; they are abstract terms covering networks of registers and isoglosses.

\footnotetext{
${ }^{49}$ Isocrates Panegyricus 50; Antidosis 296.
} 